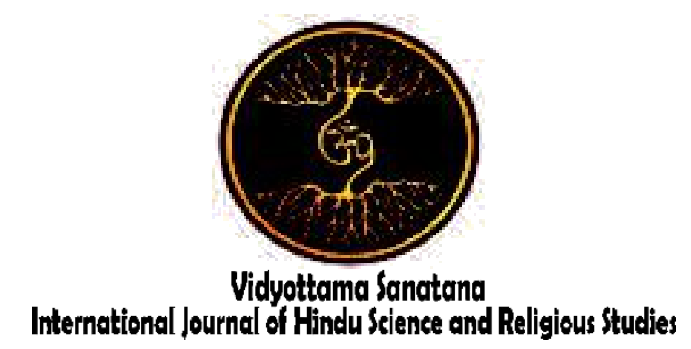

Vol. 2 No. 2 October 2018

\title{
Tradition Mēkare-Kare In Ritual Usaba Sambah In The Village Of Customary Tenganan Pegringsingan (Study of Hindu Theology)
}

\author{
By: \\ I Nyoman Subamia \\ Institut Hindu Dharma Negeri Denpasar \\ E-mail: subamianyoman@ymail.com
}

\begin{abstract}
Tradition is something that is done for generations (of ancestors) are still on the run in the community. In general, the tradition usually involves about religious elements such as religious ceremonies, as well as other religious rituals. Just as there is in the public rituals of Bali Aga village of Tenganan Indigenous Pegringsingan. Where Tenganan village is one of the traditional village which has one fairly unique tradition known as mékare-kare, where mekare-kare is war conducted in honor of the god Indra. The study was conducted in a qualitative, so the data analysis conducted qualitative descriptive and interpretative. With the data collection method is Reassurance, interviews and literature study. The results showed that: (1) The procession tradition mekare-kare is one of the most important religious ceremonies and rituals are required in Usaba Sambah in the traditional village of Tenganan Pegringsingan, include (a) the procession tradition mékare-kare, among others sangkep, gēguron, mēkare-kare mabuang pindo, mēkare-kare advanced, megibung jaja, mabuang pindo and panyineb lawang; (b) means upakara / offerings mekaré tradition-kare; (c) the place, time implementation mēkare-kare tradition; (d) equipment during mēkare-kare tradition; (e) the master of ceremonies; (f) prayer in mékare-kare; and (g) the parties concerned. (2) Function mēkare-kare tradition in ritual usaba sambah is (a) religious functions; (b) an educational function; (c) social function; (d) the survival function of indigenous traditions; (e) the function of the show; and (f) the function to train agility. (3) The meaning of tradition mékare-kare in usaba sambah rituals are (a) the meaning sradha bhakti; (b) the meaning of togetherness; (c) the historical significance; (d) the sociological meaning; and (e) inheritance value.
\end{abstract}

Keywords: tradition mēkare-kare, rituals usaba sambah, Hindu theology. 


\section{Introduction}

Tenganan pegringsingan in kabupaten karangasem bali is a provincial a village that had life ceremony of a very specific .The community tenganan pegringsingan call themselves as resident bali the aga whose ancestors came directly from india. They are not the sons of the people of java (of of majapahit kingdom) that the exodus of to bali when a big empire keruntuhannya could face because of the influence the establishment of islamic kingdoms in the northern coast of java. With the origin believed to be like that, the aboriginal peoples of tenganan pegringsingan believes that religion they came directly from india .In the doctrine and ceremonies keagamaannya has had several different to the doctrine and ceremonies hindu dharma in bali in general. The difference between 1ain, they have not known ngaben) (burning a dead body, knew no caste, admitted in common the men and women during several positions and in the social structure (korn, in 1933: 1-9).

Tenganan pegringsingan, until now were there are still quite maintained as well as the authenticity of adat-istiadatnya culture .Because of this, tenganan pegringsinganpun often becomes the icon of in on culture on the receiving end people of bali the aga. This very interesting researched remember a community bali the aga that keep traditional lifestyle until now. Obedience the community to rules village traditional that is inherited their fathers from generation to generation into a fortress sturdy from the influence of other culture in this case of majapahit bali groups are the majority of current in bali.

Entering tenganan village look and feel a sense of being ancient and modern .At ways of matchmaking those two cases can become attraction, in addition of course magical aura that come forth from the authenticity of village order closely held its inhabitants .Seen a view of a village who adheres awig-awig (of rules adat), but has mingled with the so-called modernity .Among water buffaloes do roam at liberty, seen the motorcycle village inhabitant of .In virtually every door of a house that is lined neat in the village surrounded the hills was also any clues suggesting that at the house sells cloths, namely gringsing cloth who was one of the unique characteristics of tenganan the community. Not only that, there are also demonstrations manufacturing way. All written in english.

Tourism industry that spread and while modernization, tenganan the community considered to be as bali the aga keep awig-awig they .Although awig-awig guidance of life be very honored and absolute obeyed, democratic side still radiated from their lives. Residents tenganan pegringsingan individually and collectively active to hold a hinduism according to custom the regular local .It was carried out in an hereditary manner, tersosialisasi and embedded well in the his successors. One of the things very strong to lower their identity to the next generation is to greek mythology that is told even also featured.

Tradition parents to talk to children, especially greek mythology the origin of the customary village tenganan strategy pegringsingan is learning and the inheritance of acquired noble values local culture of the people .The origin of knowledge village mythology customary tenganan pegringsingan have a very strong impact and wider at the community of his supporters .Those tenganan land as a gift god of the senses .His story originated from the god of the senses victory over to fight against the king mayadenawa an authoritarian. The world, that by civil war, considered dirty, hence needed cleansing with sacrifice a horse. Chosen oncesrawa stallion, horses belonging to a deity senses as will kurbannya. Who considered horse milky way that having white fur with a tail of a black color whose length until touching the ground .Horse believed to emerge from the sea it, escape when he announced that he will be used as cattle. Then deity senses wong paneges assigning, bedahulu soldier royal, to seek oncesrawa stallion. People paneges divided in two groups, namely: the 
first group of looking toward the west and the second group of looking toward the east .The first group did not find a horse sacrifice of the trail, while the second group managed to find the horse in a state of the dead on a place on the hillside, now called hill kaja located next to the north, village tenganan pegringsingan customary. It , immediately known by a deity the senses. Next, he said to gives grace in the form of land area of smell to defile smelt. Wong paneges, apparently ingenious, they cut up to defile the horse and brought him as far as they want. God of the senses known about it, then the god of the senses while waving, as a sign that the area that they want is enough .Areas that which is now called village as customary tenganan pegringsingan (kurnianingsih, 2008: 26).

Tradition parents to talk to children, especially greek mythology the origin of the customary village tenganan strategy pegringsingan is learning and the inheritance of acquired noble values local culture of the people. The origin of knowledge village mythology customary tenganan pegringsingan have a very strong impact and wider at the community of his supporters. Those tenganan land as a gift god of the senses. His story originated from the god of the senses victory over to fight against the king mayadenawa an authoritarian. The world, that by civil war, considered dirty, hence needed cleansing with sacrifice a horse.

Bali Aga society believe gringsing have magical powers that protect them from pain and evil forces. Tenganan is the story of people who continue to fight to preserve their identity as a proud native Balinese. Because gringsing so important in people's lives Tenganan, this fabric is like a mirror the journey of life of local communities. Until now there are those who think the red color comes from blood gringsing. Maybe red cloth used gringsing the girls in war pandan be a marker of how the severity of the noble fight. Beliefs about the magical power of the cloth and then produce its own myth. The uniqueness of this gringsing fabric, among others, which makes Tenganan
Pegringsingan have names or known in the world of tourism. This Kemahsuran survive thanks to the practice of self traditionalisation. Look, for example, how Tenganan able to bring tourists every day because of a number of life practices and traditions of the various objects is always turned on. Ceremonies into the cultural calendar Tenganan. Call such Usaba Kasa, Usaba Karo, Usaba Third, Usaba Kapat, Usaba Sambah, and so is the traditional ceremony which is present in the ritual area and awareness of the tourism industry.

The uniqueness of the tradition that owned it, not surprising that village located in Karangasem regency is often visited by tourists. They come to watch Tenganan community daily and woven fabric Pegringsingan certainly a very well-known. Especially at the time of the ceremony Usaba Sambah. Tenganan village atmosphere grew crowded, not by tourists, but also because many residents who had returned home. By the local community, this ceremony is still considered important and all components of the villagers are involved in it. Religious ceremonies in Tenganan implemented based on the Saka calendar and calendar Tenganan. Tenganan calendar is a calendar system that applies in Tenganan Pegringsingan which is still maintained as a standard calendar system in place. It is closely related to the determination and implementation of traditional ceremonies and religious in Tenganan Pegringsingan. Ceremonies were held on the basis of calendar Tenganan involving all citizens and family people Tenganan Pegringsingan sequentially in each month (sasih), in one year there are twelve months (sasih) (Fred B. Eisemarr Jr., 1988: 187).

Rite which is one component of that has to do with religious ceremonies and procedures for its implementation that involves the people and the religious spirit and belief in God, either individually or in collective community. Hindus Tenganan Pegringsingan having a local ideology Keep Satru (awake from enemy attacks) and Maulu Middle Ka (tipped into the middle) 
has been conditioned and imprinted on him through the implementation of berwarga village life and traditions of Hinduism typical berupacara Tenganan Pegringsingan (Aryandari, 2012: 10 ).

Sambah Usaba ritual is one expression of community identity Tenganan Pegringsingan. This ritual was held in the 5th (fifth sasih) in a matter of Tenganan community calendar and lasts for a full month. It is interesting to study, because the execution time is longer than the other rites, other than that this ceremony would have meaning. In this ceremony there are a series of smaller ceremonies involving various components of rural communities, ranging from parents, teens, until children. So that the entire population can be mentioned Tenganan involved with joy.

One of the important rituals in the ceremony is a tradition Usaba Sambah Mekaré-kare or Pandan War held at the end of the ceremony. This particular ritual followed by the Truna or youth in Tenganan. Each youth will fight each other with barechested and armed with some thorny pandanus leaves which functions like a sword and a shield. When the fight took place, not a few of them were injured. However, it turns out that the thug pandanus leaves it seemed not to feel pain. There are participants who let his back to the opponent carded without offering resistance.

Even though it looks like a real fight, for Truna (local youth) Mekaré tradition-kare is not a real war but simply a ritual Usaba sambah. Win or lose is not considered in this fight. The purpose of this war is not looking for a winner. The Truna believe that the blood dripping from the wound is a form of the balance of the relationship between humans and the earth as well as their respect to Lord Indra, the god of war (Ramseyer, 2009: 136). Pandan war is also a means of proving the courage Truna in Tenganan. The fewer injuries suffered by a Truna, then he will feel ashamed perhaps, it signifies that he is a coward or the like. The principle that a strong inherent in the minds Truna hard when following this ritual. Although sometimes involve deep emotion inside, it does not cause prolonged conflict. Separator interpreter will directly mediate in case of a riot. Moreover, the lads have understood very well that it would harm the holy intention behind this tradition. Another goal is to train wants to teach young people to dare to fight simultaneously sharpen their instincts. At the end of this ritual, all participants will immediately shake hands and embrace each other.

After the fight, the event continued with megibung or a meal together in a large tray filled with food and followed by all participants Mekaré tradition-kare. There was no animosity or hatred between them. Wounds all over the body that makes sad not responded with moans or cries, but with big smiles and happy laughter. Not only men, Sambah Usaba ceremony was also enlivened by Daha or girl in Tenganan to carry out a ritual, the ritual Swing. For Daha, the ceremony is also a moment to show the beauty at the same time declare their maturity. The best outfit, complete with jewelry they wear, then they got into the swing alternately. After the entire swing was filled, the circle began to be rotated manually by Truna for some time. During the spinning wheel, Daha still sit on each swing while holding the poles swing.

Swing tradition seems to have a value of its own philosophy so did the tradition Mekaré-kare full confidence philosophically. On this occasion, the authors specifically examine the traditions associated Mekaré-kare ritual Usaba sambah in Pegringsingan Indigenous Village Tenganan Karangasem regency. Given appropriate results of observations by the author find things that might have been rarely to be disclosed and the need for a study relating theological tradition Mekarékare. Behind tradition kareyang Mekaréknown by the general public as pandanus war which occurred a battle between truna (youth), was in a religious ceremony that is disclosure or implementation of Mekaré tradition gratitude, entertainment and dexterity. Initially tradition mekaré a dance 
performed by two members truna in Pura in accompanying rituals. By performing a simple dance, one truna carrying tray containing wine (drink berhakohol sourced from coconut) and one other truna bring pandan leaves are still untuh then danced together, which is done every religious ceremony at the end of the implementation of the Indigenous Village Tenganan Pegringsingan (Interview with I Nengah East, one of the traditional leaders Tenganan Village People Pegringsingan, January 25, 2015).

Sambah Usaba ceremony is a ritual that is long and the largest in Tenganan Pegringsingan. What is found in this ritual remains a unique tradition and various forms, ranging from an exciting and bloody, to the funny. Seriousness and community cohesiveness Pegringsingan Tenganan Village People in the hold of a series of ceremonies hereditary since their ancestors for a full month it is an activity that is displayed, which is now implementation has become Pegringsingan Tenganan tourism agenda. Through theological approach the implementation process will be parsed Mekaré-kare tradition as the first discussion. As a second discussion, the function of tradition Mekaré-kare. Lastly, if the meaning of the tradition mékare-kare in ritual Usaba Sambah in the Village of Customary Tenganan Pegringsingan Karangasem Regency.

\section{Result and Discussion}

\subsection{Implementation of tradition Mekaré- Kare}

1. The procession tradition Mekaré-Kare

Mekaré-kare tradition (to war with pandan leaves) is one of the most important part in ritual Usaba Sambah in Pegringsingan Tenganan Village People. This ritual was conducted in (sasih) fifth, which lasted for a full month. Sambah Usaba rituals performed during one month from the date of 5 months 5 to the 5th of the month 6 . Beginning with Patipantēt, Mamiut/Mēpamit Ngusaba in Penataran, is done every 3 days (Mēbantēn Kaja). Some further ceremony is Usaba
Sēmbangan temple ceremony at Temple Puseh, Dead Ombo Sanghyang performed for 3 days, Nyujukan swing, Multiplication Penjor, Pēbani / majak-majakan, Nulak Dhamar, Nuhu to heaven Kaja, Purnama, sangkep in Bale Agung, Nuhur to Kalan Daha , Mētebuhan, Nyangjangan Gathering Kelod, Mulan Daha, Nyengkebange / Nguduh Poh, Nyangjangan Village, Central Gathering and Kaja, ngelawang in Pura Puseh and Petung, Kare-kare Bale Agung, Maling-malingan, Mēpunjung/sangkep Truna Daha, Mabwangkala, Mēkare- kare (pandanus war), Pēngērame in Central Temu, Pēnantēnan in Banjar, Daha Nguling, Pamaridan in Pura Banjar, Mēcundang, Patipantēn Ngabut Swing, sangkep in Bale Agung, and Nyajah (Aryandari, 2012: 5758).

The circuit is so long in Usaba sambah ritual will conclude with Mekarékare. Mekaré-kare own tradition is a ritual that must be carried out every mengkahiri ceremony in the village of Tenganan Indigenous Pegringsingan, one of them in ritual Usaba sambah. Mekaré tradition-kare just a dance performed by two members truna in Pura in accompanying rituals. By performing a simple dance, one truna carrying tray containing wine (drink berhakohol sourced from coconut) and one other truna bring pandan leaves intact and danced together, which is done every religious ceremony at the end of the implementation of the Indigenous Village Tenganan Pegringsingan that until now implemented (Interview with I Nengah East, one of the leaders Tenganan Village People Pegringsingan, January 25, 2015).

In the ritual Usaba sambah which is the biggest ceremony in the village of Tenganan also featuring Mekaré-kare which can be shown to the public as a war with pandan leaves where the fight occurred between truna (youth), not only young people but also attended by parents and even children ren. It turns out in a religious ceremony that is disclosure or implementation of Mekaré-kare tradition as gratitude, entertainment and dexterity 
citizens Tenganan Pegringsingan that for a whole month to prepare the ritual Usaba sambah. The series before the traditional procession carried Mekaré-kare on Usaba sambah ritual, is as follows.

\section{a. Sangkep}

Sangkep (meeting of village manners) in Usaba sambah is a joint activity village manners. Discuss the preparation to the implementation Usaba sambah be the main agenda in this meeting, in addition to chanting samodana which has become a liability Krama village. Samodana is the text form of speech acts in carrying out the rituals. Sangkep usually done when ibulai (sunset), while samodana spoken among others: Samodana sangkep Ngundang Luanan the ritual utterances advisory meetings inviting indigenous villages, Samodana Ngambēng: ritual utterances to find sap, Samodana Nganyunang Lokan; speech swung types sajen holy ritual, Samodana Nyangjangan Village: speech ritual procession (around the village Tenganan Pegringsingan).

Similarly when Mekaré-kare, sangkep (meeting of village manners) conducted a series of ceremonies led by kelian and attended sekaa truna, village manners with his position are arranged so as to face the offerings / offerings provided in Bale Pētēmu. His position should not be arbitrary who face banten called banten pesangkēpan facing north. His position is set, at the front (1). Selonding, (2). Sekaa Truna (four truna as representative), (3). Banjar Pasek, (4). Banjar Pande, (5). Keliang Gumi and the final sequence (6). Krama village, with all facing pesangkēpan offerings. Banten pesangkēpan all prepared by members Truna. In this implementation aims ngajakin (sangkep ngajakin). Furthermore keliang convey words by using language typical of Tenganan Pegringsingan like "sampun betel palm wine keteben idane" meaning whether all get wine. After sangkep in Bale Pētēmu completed, the next back special for village manners sangkep place in the Bale Agung
(Interview with I Nengah East, figures Tenganan Village People Pegringsingan, March 16, 2015).

\section{b. Gëguron}

Gēguron according to the explanation I Wayan Mudita custom figures derived from the word kaguruan which means teachers and songs. Gēguron is a sacred procession which marks the opening of Mekaré-kare will begin, with menabuhkan (singing) gending Selonding called gising Gēguron using Selonding. Gending Gēguron including gising sacred or hallowed. There are times when the rhythm Selonding should not be recorded using a tape recorder or a camcorder, which when Mekaré-kare will begin. Since Tenganan serve as a tourist destination sanctity tolerate profanism. The outsiders are allowed to see and listen to all the sanctity of Tenganan, including immortalize through photographs or video. So when Selonding will begin, some youths Tenganan have a duty to inform tourists or spectators Mekaré-kare so deadly handycamnya for about ten minutes.

Gending Gēguron always dimaikan at the start of a ceremony. Gending relatively little slow and easy to remember penabuhnya. Usually this gending sounded when will start the scene of the ceremony, as a sign inviting god (Ernst Sclager in Aryandari, 2012: 122). There are times as a sign of their activities to prepare the ritual instruments, such as when there were first beaten Gēguron called Gēguron Nyuang Tuak where Krama village collect palm wine prepared in Bale Agung, and there are also socalled Gēguron Nēdunang Rice, as a sign calling Krama village to bring rice to Bale Agung. After all the preparations completed, stakeholders said it was ready nyiyasin Bhatara, then ditabuhkan Selonding with gending Gēguron Nyiyasin.

\section{c. Mekaré-kare Mabuang Pindo}

Mabuang Pindo a procession offered the sacred dance performed by two people 
truna dilakuakn 2 times as symbolic pandanus war will begin. Starting with the two village manners pretend to fight, then followed by all manners with wine Mider and then proceed to throw palm wine (mêtabuh) as a sign of dedication to the land (Mother Earth). After Mider wine (wine share respectively), then all holding village manners pandan leaves and go hand in hand around the page Bale Pêtēmu the opposite direction to clockwise.

\section{d. Mekaré-kare Continued}

Continued Mekaré-kare is a top event execution pandanus war began. Before the fight started there was a procession around the village residents called melelawang accompanied by drumming Baleganjur. On several occasions there were people who helped procession trance. Mēbaris procession is carried out by residents banjo Pande led by stakeholders.

Pandanus war typically lasts for two days. The first day is done at dusk by indigenous villagers Tenganan Pegringsingan, and the second day is done by the residents and the general public. On the second day, the war carried on stage. To start Mekaré-kare traditional leader in the village of Tenganan deliver on cue with a loud voice. Two young men get ready. They were face to face with a bunch of pandan leaf in his right hand and a shield (made of woven leaves ata) in the left hand. Mediators, like a referee, standing between two youths. After the arbitrator raised his hands high, both young men attacking each other. They hit the back of an opponent in a way embrace first. They grappled, drag each other back an opponent with barbed pandanus leaves. That's why this ritual is also called mēgeret pandan.

\section{d. Megibung Jaja}

Activities performed at each meal with a ritual in Tenganan Pegringsingan. This activity is often referred to nyacah. In nyacah, usually served chopped containing rice with pork. There is also an activity that jambal nyacah eat together with chopped jaja. In addition there is a tradition called nyacah megibung. Megibung tradition or eat together in one container is also known as bancakan. In the tradition-kare Mekaré also performed megibung is megibung jaja. A meal together after the war was doing pandan which contains a wide variety of snacks. In the tradition of this jaja megibung unique blend of all participants regardless of social status.

Meaning megibung is a process or activity carried out by the community or group of people sit together to share with one another, especially in terms of food. Megibung has now become a unique tradition typical of Karangasem. This activity is an ancient tradition of heritage Kingdom of Karangasem, Bali. Traditions are created to increase the sense of community residents. Megibung derived from the word gibung which means activities carried out by many people to share with one another, while his prefix means doing an activity.

\section{f. Mabuang Pindo}

Before Mekaré-kare ended, will return to do the same dance Pindo mabuang as has been previously described above. This dance is actually named abuang, because sudh move then called mabuang. Mabuang as offering one of the sacred dance that represents compassion, love as the duties and obligations in the life of the village and berupacara berwarga Hinduism in Tenganan Pegringsingan.

\section{g. Panyineb Lawang}

Penyineb mace is the last in a series of ceremonial procession tradition Mekarékare. At this procession carried mecane given to members of village manners after Mekaré-kare by truna, in which the material is composed of diulig rice (rice were destroyed as into flour, turmeric, porosan and betel nuts are made by members of Daha. Cane aimed begging grace to the ancestors and gods after Mekaré-kare waranugraha may be given to all residents as well as all the activities 
given Tenganan fluency in everyday life. Furthermore, the event mererean and sangkep in Bale Agung by Krama village and the procession nyimpen Truna to restore equipment such as Selonding, as well as equipment-kare Mekaré traditions that are kept back in place using pakēpuak offerings.

\section{Means Upakara / Banten tradition Mekaré-kare}

Implementation of a tradition covering of the ceremony can not be separated from the means upakara / offerings is needed to run properly and smoothly. Similarly, the related series Mekaré traditionkare, necessary means upakara which must be prepared by members of the community Tenganan Pegringsingan in Usaba sambah ritual.

Upakara comes from two syllables that upa and kara, which upa means "middleman" (trailing, Balinese) and syllables kara can be interpreted worship. So upakara may contain a notion that is as a means of intermediary upakara of bhakti Hindus worship presented to Ida Sang Hyang Widhi Wasa (Sudarsana, 2001: 11). In general in Bali upakara also called the offerings. Banten word also has a sense similar to upakara, only seem to have a character that is building a sense remember cetana presented to the Creator, and an education to stay aware of personal identity as a human being (Ramiati, 2006: 83).

Banten is derived from the word "Bangten" consists of a syllable of "Bang" and "graft" (Balinese). Bang syllable could be interpreted Brahma and Brahma becomes Brahman (Sang Hyang Widhi). While the "graft" can mean "remember" or are made aware of (cetana). So said banten implies, that Hindus make offerings, to educate himself so always remember to Sang Hyang Widhi existence, because $\mathrm{He}$ is the creator of all the contents of this world (Sudarsana, 2001: 13)

Banten is sacred offerings are made of certain facilities, such as: flowers, fruits, and such as betel leaf and from foods such as rice with side dishes, snacks and so on, in addition to other crucial vehicle is water and fire (Titib, 2003: 134). In line with the opinion of Geertz in "Religion as a Cultural System" which he defines as: (1). A system of symbols that play a role, (2). Build mood and motivation strong, pervasive, and long lasting in humans dean manner, (3). Formulate a common conception of the order of life, (4). Wrap these conceptions with such an aura of factuality so, (5). Moods and motivations seem uniquely realistic (Pals, 2001: 414). Making offerings as expressing feelings can be a disclosure of gratitude, apologize, ask grace and so on.

Banten with all forms, names and of different materials actually means offering containing a high philosophical significance. By means of offerings Hindus expressed gratitude to Ida Sang Hyang Widhi Wasa, therefore it is a symbol of religious offerings. In connection with this, then the tradition-kare Mekaré used means of offerings. Offerings made by the community Tenganan Pegringsingan slightly different from the Hindu community in Bali in general, more simple unadorned reringitan complicated. Such offerings used in Mekarékare is among others:

\section{a. Banten Pesangkepan}

Banten is used when the procession pesangkepan placed in Bale Pétēmu made simply without diminishing sourced from local produce. The contents of offerings pesangkepan upakara means that bananas, flowers, rampe (urab-Uraba) / nuts and snacks.

\section{b. Banten Pakepuak}

Banten pakepuak used when the procession finished abuang Pindo other words the closing ceremony, where in Bale Pétèmu number 2 from a simple selonding made without reducing the meaning sourced from local produce. Fill upakara means of offerings as a whole pakepuak pesangkepan offerings, only different from the container/pads are used, offerings pakepuak using container/ironing nare. 


\section{Place, Time of Tradition Mekaré-Kare}

Hindu religion believe that God is everywhere. The nature of God is not terbasahkan by water, burned by fire, not by fire terkeringkan, unblemished by sin, and so forth, because he is without form, without form, not men, not women and the unborn, as he mentioned properties with "neti -neti ". God also called almighty, omnipotent, allknowing, all-work, no space that is not occupied by him in accordance with the nature and swabhawaNya, he called immanent that are as close to the bottom of my heart on the inside, and he was transcendet as far as possible. Based on the nature of God, it means that Hindus can perform persembhayangan, ceremony anytime and anywhere.

All of confidence in the nature and swabhawa God (Hyang Widhi) like that, Hindus still have ethics in closer himself to Ida Sang Hyang Widhi Wasa in the implementation sembhayang and ceremonial activities. This ethic appears due sembhayang activities and ceremonial activities include social issues and the sanctity of the human mind, then the problem of the place and time be the deciding factor as well. It means praying in the middle of the road umu, in the market, because they interfere with people passing by, is not justified. Likewise, prayer in a place less in place and in a place that is not feasible may otherwise not well. Similarly, the element of time (kala and Dauh) are expected to use the time as well as possible in order not to be affected by the negative traits of the time. To that end, in the tradition of ritual Usaba Mekaré-karedalam sambah should also be disclosed where and when the activity was carried out. Mekaré tradition-kare is made such that, in accordance with the ethics and aesthetics. Mekaré-kare place in each end of the ceremony in the village of Tenganan Ceremony held at the temple Banjar that only a Mekaré-kare dance performed by two (2) people truna without a war. While specific in ritual Usaba sambah, Mekaré-kare besides danced in Banjar Temple was also staged and shown to the public as agility contest, entertainment and prostration of gratitude joy which is dedicated to Lord Indra who carried on the front page Pêtēmu and Bale Bale Agung. Furthermore, the implementation time-kare Mekaré in Usaba sambah ritual, which determines a good day (Adults Ayu), which is adjusted by a series of rituals Usaba sambah ie at the time panglong pingdasa sasih to five, and the time after 12 noon until the finish, where the sun has begun leaning to the west (Interview with I Wayan Mudita and I Nengah East, figures Tenganan Village People Pegringsingan, March 16, 2015).

\section{Equipment On-Kare When Mekaré Tradition}

Mekaré tradition-kare use some of the equipment as a symbol (symbol) which has a specific meaning and significance that we should preserve because of the presence of such symbols, Maha Rsi guiding and educating his people to understand the noble values of the teachings of Hinduism is contained in every ceremony is held. As for some of the equipment used in connection with the tradition Mekaré-kare in Usaba sambah in Pegringsingan Tenganan Village People, among others, using (1) a shield made of ata, (2) the weapons of thorny pandanus leaves taken from tananam around the house with the size of the cut along about 15 then tied up as much as $10-15 \mathrm{~cm}$ strand, (3) use pakian gringsing cloth clothing, gloves and headband (Udeng) with shirtless (without clothes). As a result of the wounds of war pandan scratches treated by traditional herb that created by the community Tenganan hereditary. That is called Boreh, made from herbs that galangal, turmeric, vinegar mixed into one. On the second day Mekaré-kare made in Bale Pētēmu stage that measures approximately 4 x 6 square meters. With a height of about 1 meter, the stage is really like a boxing ring. The difference without a safety rope surrounds. Safety is the pamedek (people involved in the ceremony) itself. So the pamedek who sit on the edge is always asked to be vigilant, given the participants Mekaré- 
kare could fall on the audience when a fierce battle dank eras on stage.

\section{Leaders Ceremony}

Every religious ceremony master of ceremonies must exist. Likewise, in the tradition of Mekaré-kare is usually a master of ceremonies stakeholders (Pinandita) who have already mastered the Ekajati and eedan of the ceremony is meant, according to the Indigenous Village Tenganan dresta Pegringsingan. In addition, the lead upakara when Mekaré-kare is Jro Kelian Village People number one, who took the lead when pesangkepan familiar and master stages and eedan upakara intended.

\section{Prayer / Mantra in the Tradition Mekaré-Kare}

Upakara prayer in every religion is something that alongside upakara and master of ceremonies. Like a coin when one side does not exist then the money is useless and functioning. Similarly, among the mantra or prayer with a ceremony. For the people of Tenganan Village People Pegringsingan in ceremony Mekaré-kare mantra or a prayer sung by the master of ceremonies that followed atmanastuti by village manners confidential, so the authors in this study did not have the authority to include. In accordance with the delivery figures when interviewed local residents, is not allowed to publish a spell in the tradition in question. And mantra or prayer is only revealed to the position holders are ongoing selanjutan (Interview with I Wayan Mudita, I Nengah East, I Nengah Madri and I Putu Yudiana, ST as a figure Tenganan Village People Pegringsingan, March 16, 2015).

\section{The Related Parties}

Mekaré tradition-kare is not just a private matter of the parties being melaksanan the ceremony, but an Indigenous Village Tenganan Pegringsingan ceremony involving family, friends, community, and indigenous prajuru. Besides Indigenous villagers Tenganan Pegringsingan as the core, which involved also from outside the traditional village called Village Pasuwitra. Which includes the village of Tanah pasuwitra Aron, Asak, crying, and Tenganan Dauh Tukad. In other words Mekaré-kare tradition in the village of Tenganan Indigenous Pegringsingan a family affair, indigenous people or institutions who witnessed the execution of the ceremony.

People related to the implementation of Mekaré-kare tradition in ritual Usaba sambah in Pegringsingan Tenganan Village People, among others: All Villages Tenganan Pegringsingan, Jro Mangku, Sarati I artisan offerings as pengayah, prajuru traditional village and Village Pasuwitra.

\subsection{The function of tradition Mekaré- Kare In Rituals Usaba Sambah}

Structural functional theory in this study will be used to examine the ceremony in the functional definition, what is the role of tradition in the ritual Mekaré-kare Usaba sambah that in answering the question of life faced by Hindus in Bali, especially the Tenganan Pegringsingan. In the vertical dimension upward Hindus in Bali is a religious society. Thus every ceremony performed an effort to meet the needs of his inner man like; the desire to always be bound to the Supreme Creator, the Almighty God, also the awareness of the stain and sin on themselves, which in turn led to a form of human endeavor ceremony as a vehicle for self-purification and refinement.

a) Religious functions, namely, it is understood to have great significance in the implementation yajna yajna even though implementation is not attached to the outcome, but have spiritual goals, among others, (a) to connect themselves with Ida Sang Hyang Widhi / God in the manifestation of the god Indra ; (B) as a sign of gratitude for all the grace that has been bestowed him; (C) to achieve purity, cleanse themselves of sins, to achieve inner and outer perfection; (D) to improve Sradha Bhakti ancestral indigenous villagers and Ida Sang Hyang Widhi Wasa. 
b) Educative function, through tradition-kare Mekaré able to educate in behavior (ethics) in a ceremony also serves to increase adherence to bhisama indigenous villagers who had been handed down by ancestors. And also a lesson for the next generation to obey the rules or norms that have been agreed upon by the community. So that the traditional values Mekaré-kare or pandanus war contributes to education. Mekaré tradition-kare or pandanus war so have a correlation with education, especially to the author observed during the study that Civics like, please Almighty God, humanity, unity, consensus, justice, tolerance, a sense of responsibility, and obey on regulation.

c) Social function, traditions Mekaré-kare is not just a private matter of the parties who are conducting the ceremony but also involve the family, relatives, society or custom banjo. Involvement of various parties in the implementation of a ritual that is able to show good cooperation will demonstrate the achievement of a goal Yajna are good also, the more elements of the yajamana, serati (artisan offerings), pinandita or pastors and community supporters of the ritual can work well together according to function, then a ritual will be implemented well too. So socially is to work to improve cooperation, kinship between village manners with each other. The procession implementation Mekaré-kare tradition involves a lot of village manners, sekaa truna and villages pasuwitra and common citizens or the audience both locally and abroad who wish to try the tradition Mekaré-kare is also permitted.

d) The function of the survival of indigenous traditions, raises a policy that has been designed in a manner that is done in maintaining the tradition Mekaré-kare, such as traditional education metruna nyoman, still carry the tradition Mekarékare, will grow a sense of pride in their own culture, truna include (youth) and create a museum culture. e) The function of the show, a tradition-kare Mekaré featuring folk games that blend with the ritual procession, making a unique and enthralling performances witnessed for so packed watched by local and foreign tourists as the show. In appearance pandanus war there are some aspects of the game, ceremonies, and a ritual drama, everything happened and felt at the same time. As a folk game, pandanus war is certainly not a war in the true sense. Playing is an activity that is done but it is not a real thing or earnest.

f) Function train agility, which shows the dexterity of a man. Because by following this pandanus war youth are trained to protect themselves from attack opponents, and the young man how to make the opponent into defeat. Agility in pandanus war myriad forms one of which is hand dexterity, the pandanus war supplies used one which is pandan pandanus war when implementing using the technique of hand speed so as to the opponent, that opponent to lose and give up. Another dexterity dexterity eye which in this tradition is the eye trained to accurately so that we are able to know the parts that want to attack, with the dexterity of implementing this then trained to be more rigorous.

\subsection{Meaning of Tradition Mekaré-Kare In Rituals Usaba Sambah}

Symbols serve to guide the understanding of the subject object (Triguna, 2000: 7). In a certain sense, a symbol often have a deep meaning, which is a concept that is most valuable in the life of society, as well as religious symbols are highly respected by the people concerned. Related to the above, the symbol can be dimensionless horizontal and vertical immanent transcendent with "markers" and "markers". Marker is a symptom or form and the marker is the essence or meaning.

a) The meaning of sraddha and devotion associated with the belief that can not be separated from the concept of Hindu religion as a way of sacrifice sincere devotion of the people Tenganan 
Pegringsingan to the gods in pujanya namely Indra.

b) The meaning of togetherness, which together are referred to the gathering of young people (truna daha) of several hamlets in the village of Tenganan Pegringsingan gathered to organize pandanus war tradition, so that the spirit of togetherness will emerge in the form of mutual assistance in carrying pandanus war. Other togetherness is embodied in the citizen pandanus war participants coming from outside the Village People Tenganan Pegringsingan can follow pandanus war. Thus this tradition is open and able to familiarize local people with other people, and finally this tradition is able to foster a sense of togetherness, unity and integrity.

c) The historical significance, shows the myth that living in Tenganan into text that is important to uncover people's behavior. This relates to a series of reactivation measures in order ritually meaning of life, or spirit, or behavior contained in the soul and history into the minds of the people of Tenganan Pegringsingan. Either in conjunction with a larger force of nature or with other humans.

d) Sociological meaning, to establish harmony / kinship between citizens and tradition-kare Mekaré will also move other elements in society.

e) The meaning of inheritance value, where tradition Mekaré-kare in Tenganan Pegringsingan still uphold and maintain our culture as the original because people assume that the culture is inherited from ancestors and they did not dare change in the sense of not dare to diminish or add anything to the slightest of culture- culture they have.

\section{Conclusions}

Based on the description in Chapters mentioned above it can be delivered the following conclusion:

1. Process Mekaré-kare tradition is one of the important and mandatory part of the ceremony in the ritual Usaba
Sambah in Pegringsingan Tenganan Village People. The circuit is so long in Usaba sambah ritual would end with a display Mekaré-kare which can be shown to public widely as war with thorny pandanus leaves which occurred a battle between truna (youth), not only young people but also attended by parents and even children ren. It turns out in a religious ceremony that is disclosure or implementation of Mekaré-kare tradition as gratitude, entertainment and dexterity citizens Tenganan Pegringsingan that for a whole month to prepare the ritual Usaba sambah. The series before the traditional procession carried Mekaré-kare on ritual Usaba sambah, covering sangkep, gēguron, Mekaré-kare mabuang pind, Mekaré-kare advanced, megibung jaja, mabuang Pindo and panyineb mace. It is not independent of the means upakara / offerings are prepared, place, time of execution, equipment, master of ceremonies, prayer / mantra and the parties related to the tradition Mekaré-kare.

2. Functions Mekaré-kare tradition in ritual Usaba sambah in Indigenous Village Tenganan Pegringsingan is: religious function, educative function, social function, the function of the survival of indigenous traditions, performing functions, and functions to train agility.

3. The meaning of the tradition of the ritual Mekaré-kare Usaba sambah in Indigenous Village Tenganan Pegringsingan namely Meaning Shraddha and related bhakti, meaning togetherness, historical significance, sociological meaning, and the meaning of inheritance value.

\section{References}

Aryandari, Citra. 2012. Ritual Usaba Sambah: Sebuah Babak dalam Kehidupan Masyarakat Tenganan Pegringsingan, Bali (Disertasi). 
Yogyakarta: Universitas Gadjah Mada Yogyakarta.

Astra, Semadi, dkk. 2001. Kamus SanskertaIndonesia. Proyek peningkatan Sarana dan Prasarana. Pemda. Propinsi Bali.

Berger, Arthur Asa. 1984. Signs in Contemporery Culture: An Introduction to Semiotics. New York: Longman Inc.

Bogdan, R dan Taylor, J.S. 1992. Introduction to Qualitative Reseach Methods, alih Bahasa Arief Furchan, Edisi I, Usaha Nasional, Surabaya.

Cassirer, Ernest. 1990. Manusia dan Kebudayaan: Sebuah Esei Tentang Manusia (diterjemahkan dari judul asli An Essay on Man oleh Alois A. Nugroho). Jakarta: Gramedia.

Dillistone, F.W. 2002. Daya Kekuatan Simbol (The Power of Simbol). Yogyakarta: Kanisius.

Donder, I Ketut. 2006. Brahmavidyā: Teologi Kasih Semesta (kritik terhadap epistemologi teologi, klaim kebenaran, program misi, komparasi teologi, dan konversi). Surabaya: Pāramita.

Donder, I Ketut. 2007. Kosmologi Hindu: Penciptaan, Pemeliharaan, dan Peleburan Serta Penciptaan Kembali Alam Semesta. Surabaya: Pāramita.

Donder, I Ketut. 2011. Teologi Sosial: Persoalan Agama dan Kemanusiaan Perspektif Hindu. Surabaya: Pāramita.

Eliade, Mircea. 2004. Myth and Reality dalam Robert A.Segal (ed.) The Myth and Theory. Oxford: Blackwell.

Fred B dan Jr. Eiseman. 1998. Bali: Sekala \& Niskala, Essays on Religion, Ritual, and Art, Vol. I. Singapore: Perriplus.

Gara, I Wayan. 2006. Wacana Samodana Usaba Sambah pada Masyarakat Tenganan Pegringsingan: Sebuah Kajian Linguistik Kebudayaan. Disertasi untuk memperoleh derajat Doktor dalam Ilmu Sastra, Universitas Udayana, Denpasar.
Geertz, Clifford. 1992. Tafsir Kebudayaan (Diterjemahkan dari judul asli The Interpretation of Cultures: Selected Essays oleh Budi Susanto SJ.). Yogyakarta: Kanisius.

Imamatul, Awaliyah. 2013. Definisi Desa, Kota, Pedesaan, dan Perkotaan. (Online), (http://www.awaliyahhasanah.blogsp ot, diakses 29 Januari 2015).

Junitha, I Ketut. 2015. "Struktur Genetika Masyarakat Bali Aga Tenganan Pegrisingan Karangasem Berdasarkan Penanda DNA Mikrosatelit" dalam materi diskusi "Bali Tempo Doeloe\#13Bioantropologi: Tenganan Pegringsingan dalam Dua Perspektif" Jumat, 27 Maret 2015. Denpasar: Bentara Budaya Bali.

Hasan, Igbal. 2002. Pokok-Pokok Penelitian dan Aplikasinya. Jakarta : Indonesia Ghalia.

Kaelan, H. 2010. Metode Penelitian Agama Kualitatif Yogyakarta: Paradigma.

Korn, V.E. 1933. The Village Of Tenganan Pegringsingan. Santpoort: The Liefrink-Van der Tuuk Foundation.

Korn, V.E. 1933. De Dorspsrepubliek Tenganan Pegringsingan. Santpoort: Uitgeverij C.A.Mees.

Kurniangsih, Ambarwati. 2008. Simulacra Bali: Ambiguitas Tradisionaslisasi Orang Bali. Yogyakarta:Insispress.

Madja, I Ketut. 2008. Konsep Yoga Patanjali dan Wrhaspati Tattwa (Sebuah Studi Komparatif) (Tesis), Denpasar: IHDN Denpasar.

Mantra, Ida Bangus. 1995. Bhagawadgita (Alih Bahasa \& Penjelasan). Denpasar: Pemerintah Daerah Tingkat I Bali.

Moleong, Lexy J. 2005. Metodelogi Penelitian Kualitatif. Bandung : Remaja Rosdakarya.

Monier, Sir M. William. 1990. SanskritEnglish Dictionary. Delhi: Motilal Banarsidass. 
Mulyana, Dedi. 2001. Metodelogi Penelitian Kualitif, Paradigma Baru Ilmu Konikasi dan Ilmu Sosial Lainnya. Bandung, Remaja Rosdakarya.

Nala, I Gst. Ngurah dan I.G.K. Adia Wiratmadja. 2012. Murddhana Agama Hindu. Denpasar: Upada Sastra.

Ngurah W. 2013. Mekare Kare Atau Geret Pandan di Tenganan. (Online), (http://bengkelredaksi.blogspot.com, Sabtu 4 April 2015).

Pals, Daniel L. 2001. Seven Theories of Religion (alih Bahasa : Ali Noer Zaman). Yogyakarta: Qalam

Picard, Michel. 2006. Bali Pariwisata Budaya dan Budaya Pariwisata. Jakarta: KPG.

Poerwadarminta, W.J.S. 1984. Kamus Umum Bahasa Indonesia. Jakarta: Balai Pustaka.

Pudja, I Gede. 1986. Pengantar Weda. Jakarta : Dep. Agama RI.

Pudja, Gede. 1992. Teologi Hindu (Brahma Widya). Jakarta: Yayasan Dharma Sarathi.

Pudja, Gede. 1995. Sama Weda : Text dan Terjemahan. Jakarta: Hanuman Sakti.

Ramiati, Ni Made. 2006. Tradisi Naur Kelaci Dalam Upacara Perkawinan Di Desa Adat Munduk Lumbang, Baturiti, Tabanan. (Tesis). Denpasar: IHDN Denpasar.

Ramseyer, Urs. 2009. The Theatre of the Universe Ritual and Art in Bali. Switzerland: Museum der Kulturen Basel.

Redana, I Made. 2008. Metode Penelitian Dengan Contoh-Contoh Penelitian dan Karya Ilmiah. Denpasar : IHDN Denpasar.

Satori, Djam'an dan Komariah, Aan. 2010. Metode Penelitian Kualitatif. Bandung: Alfabeta.

Soedarsono, R.M. 1999. Seni Pertunjukan Indonesia dan Pariwisata. Bandung: MSPI
Subiyantoro, Heru. 2008. Ekspedisi Tenganan Pegeringsingan Bali.

(Online),

(https://herusu71.files.wordpress.com , Selasa, 10 Maret 2015).

Sudarsana, Ida Bagus. 2001. Ajaran Agama Hindu (Filsafat Yadnya). Denpasar: Dharma Acarya.

Suharsini. 2002. Prosedur Penelitian Studi Pendekatan Praktek. Jakarta : Rineka Cipta.

Sunariani, Ni Nyoman. 2014. Kontribusi Pelaksanaan Ritual Terhadap Kesempatan Kerja dan Kesejahteraan Masyarakat: Studi Kasus Mlaspas dan Ngenteg Linggih Di Pura Pasek Preteka Desa Abiansemal Kecamatan Abiansemal Kabupaten Badung (Disertasi). Denpasar: Universitas Udayana.

Supartha, Wayan. 1999. Bali dan Masa Depannya. Denpasar :PT. Offset BP Denpasar

Supartono. 2004. Ilmu Budaya Dasar. Jakarta :Ghalia Indonesia

Tim Redaksi. 2008. Kamus Besar Bahasa Indonesia. Jakarta: PT Gramedia Pustaka Utama.

Titib, I Made. 1996. Veda Sabda Suci (Pedoman Praktis Kehidupan). Surabaya: Parāmita.

Titib, I Made. 2003. Menumbuhkembangkan Pendidikan Budhi Pekerti Pada Anak (Perspektif Agama Hindu), Jakarta : Parisada Hindu Dharma Indonesia.

Triguna, I.B Yuda. 2000. Teori Tentang Simbol. Denpasar: Widya Dharma.

Wiana, I Ketut. 2002. Memelihara Tradisi Veda. Denpasar: PT. Offset Balipost.

Yayasan Bali Galang. tt. Menurut Cara Menjalankannya (Panca Marga Yadnya). (Online), (http://www.babadbali.com, diakses selasa 7 april 2015). 